\title{
The Relationship among Electricity Consumption and Economic Growth in Turkey (2000-2017)
}

\author{
Murat Acet \\ Bolu Abant Izzet Baysal University \\ Finance-Banking and Insurance Department, Bolu, Turkey \\ E-mail: acet_m@ibu.edu.tr
}

\begin{abstract}
Today, both developed and developing countries industries are using mainly fossil fuels. This situation entails environmental hazards and sustainability threatening risks as well. Production from renewable energy sources many may solve the environmental and the other problems. Electricity is an energy source that can not be ignored important contribution in terms of economic growth.

If this condition which energy consumption rate of the developed countries, higher than in other countries is considered, In order to achieve the targeted economic growth, Turkey's energy production and consumption need to pay attention.

In this study, on the relationship between electricity consumption and economic growth, during the period between 2000-2017 in Turkey, is discussed. As it performed previously in several studies, in this study, the close relationship between electricity consumption and economic growth was determined.
\end{abstract}

Keywords: Energy Economics, Electricity Consumption, Economic growth.

DOI: $10.7176 / \mathrm{JSTR} / 5-8-09$

\section{Intruduction}

Energy is an indispensable element of both industry and daily life. It is directly related to economic growth with its use in production and with economic development with its use in life. In addition, countries that control energy resources in the this century have a more important bargaining power both economically and politically, and are effective and decisive in drawing the world's eco-political course.

In this context, many studies show that there is a close relationship between the amount of energy use and economic growth of countries. Many studies conducted in the field of energy economics, which is a subdiscipline of the science of economics, reveal that it is a condition for countries to have energy resources and to use this energy efficiently and to achieve a higher standard of living.

However, although there are many different alternatives in terms of the way in which energy sources are obtained, the fact that the world is more oriented towards fossil fuels in production and consumption brings many problems especially in terms of environmental problems and sustainability.

It is a common approach to classify energy sources as primary and secondary energy sources. Primary energy sources: coal, crude oil, natural gas, wind, sunlight, water power, and secondary energy sources, primary energy sources obtained or converted using energy sources, one of the most characteristic examples of this is electrical energy.

Primary energy sources can be divided into two subgroups, renewable and non-renewable. While solar, wind, wave, geothermal energies are renewable energy types, energy types such as crude oil and natural gas are non-renewable.

Unfortunately, a significant part of the types of energy that we use today and are also used in production as the main energy input of the industries are non-renewable primary energy sources such as crude oil and natural gas.

This also indicates that the world is moving towards an energy shortage in the future.

Now the whole world needs to see the fact that renewable and secondary sources of energy are alternatives to fossil fuels and begin to make the necessary transformations. Although the use of hybrid systems in many sectors, especially in the automotive sector, can be considered as the pioneering steps of this process, it is 
difficult to argue that these efforts are sufficient. In this context, the importance of electrical energy, which is a secondary energy source, is increasing day by day due to both environmental sensitivity and being an alternative to fossil fuels.

It cannot be argued that electric energy, which is a secondary energy source obtained from renewable energy sources, will contribute to economic growth with the use of it in industry and economic development with its use in daily life.

Numerous studies conducted in many countries in this field try to establish the relationship between economic growth and the use of electrical energy. The relationship between the use of electrical energy and economic growth has been investigated for many periods in our country.

In this study, the relationship between electrical energy consumption and economic growth of countries is discussed with reference to previous studies. Especially with the use of electrical energy in terms of relations between Turkey economic growth, examining the period between the years 2000-2017, we will strive to put forward the relationship between these concepts. Therefore, the dimension that the study aims to contribute can be summarized as updating the studies in the current literature.

\section{Current Literatures}

R. Ferguson's comprehensive study is a pioneering work that explores the relationship between the use of electrical energy and economic growth. In this study, the relationship between electricity consumption and economic development is examined in terms of 100 countries and it is revealed that there is a strong relationship between these two concepts.(Ferguson, vd., 2000)

There are many studies in the literature aiming to reveal the relationship between electrical energy consumption and economic growth. These studies differ from each other, either in terms of the time period in which they are addressed, or in terms of examining the relationship between the use of electricity and growth, emphasizing differences in the place of use of electricity (housing, industry, etc.). For example, in some studies, the relationship between electrical energy consumption and economic growth used in houses has been examined. In some, the relationship between electrical energy consumption and economic growth in industry has been examined. In many of them, no such distinction has been made, and the relationship between total electricity consumption and economic growth has been examined as a holistic period of time. Another important study in the field of energy was made by Kraft and Kraft (1978). This study was followed by Akarca and Long (1980). Stern (1993) added energy to the production function.

In the early 2000s Ghosh (2002) examined the relationship between economic growth and electricity consumption for India in 1957-1997. It has identified a one-way causality from economic growth to electricity consumption.

Shiu and Lam (2004), Thoma (2004), Morimoto and Hope (2004), and many researchers in various countries in their studies on the use of electrical energy has determined that affect economic growth.

Mozumder and Marate (2007) in his study on Bangladesh and Squalli (2007) in his study on 11 OPEC countries found that economic growth affects the use of electrical energy. However, such studies are less frequent than others. The majority of the studies in the literature indicate that the use of electricity affects economic growth.

In a study conducted in 2005 he has made Altınay and Karagöl GDP and electricity consumption in relation to the 1950-2000 year in Turkey. They found unidirectional causality from electricity consumption to GDP. In 1996, Murray and Nun, dealt with 15 countries for the period 1970-1990 is also in Turkey.

Terzi (1998), the period of 1950-1991 electricity consumption in terms of different consumers (housing, industry, etc.) has been addressed individually. Engle-Granger's cointegration method revealed a long-term relationship between these two variables.

Yamak and Güngör (1998) study of the period 1951-1994, Bakirtaş et al. (2000) the period of 1962-1996, Sar1, Soytaş and Özdemir (2001) of the period of 1960-1995, Nişanc1 (2005) of the period of 1970-2003, Erdoğdu (2006) of the period of 1984-2004, Halıcioğlu (2007) of the period of 1968-2005, Karagöl, Erbaykal and Ertuğrul (2007) discussed the 1974-2000 period in their studies.

In Turkey, between 1980-2000, economic growth increased by 4\%, electricity consumption increased on average by $8 \%$. While electricity consumption per capita has been $452 \mathrm{kWh}$ since 1980 , this figure was $1687 \mathrm{kWh}$ in 2004 but compared to $8600 \mathrm{kWh}$, which is the average of OECD countries. (Karagöl et al., 2007)

The common finding of all the studies in this field is that there is a long-term relationship between the consumption of residential and industrial electricity and economic growth. The fact that electrical energy consumption in the industry has started to increase with economic growth only shows that the relationship

81 | P a g e

www.iiste.org 
between electrical energy consumption and economic growth in residential areas is a two-way causality relationship. (Kar, 2001)

In almost all of the studies mentioned above, the existence of long-term relationship between electrical energy consumption and economic growth was determined by Johansen Cointegration Test, and the causality and direction were tried to be determined by Granger and Vector Error Correction Mechanism (VECM).

\section{Method and data}

In this study, Total Electricity Consumption (ELEK) and GDP (BUY) data were taken from TUIK database. The annual data used in the study covers the period 2000-2018. Electricity consumption data were used logarithmically. Growth is considered as the annual rate of change of GDP.

Stability and causality tests were conducted using eViews. Generalized Dickey-Fuller (ADF) test was used in the stationarity test. Total Electricity Consumption and GDP data were stabilized in I (1). Failure to maintain stability in the series used in similar studies brings the risk of the analysis to be faced with false regression. Therefore, the stability of the series was determined first.

The Granger causality test was calculated in the E-Vievs program using the following equations.

$$
\begin{aligned}
\text { LBuy }_{\mathrm{t}} & =\sum_{\mathrm{i}=1}^{\mathrm{n}} \mathrm{a}_{\mathrm{i}} \text { LBuy }_{\mathrm{t}-1}+\sum_{\mathrm{i}=1}^{\mathrm{n}} \mathrm{a}_{\mathrm{i}} \text { LElek }_{\mathrm{t}-1}+\varepsilon_{\mathrm{i}} \\
\text { LElek }_{\mathrm{t}} & =\sum_{\mathrm{i}=1}^{\mathrm{n}} \mathrm{a}_{\mathrm{i}} \text { LElek }_{\mathrm{t}-1}+\sum_{\mathrm{i}=1} \mathrm{a}_{\mathrm{i}} \text { LBuy }_{\mathrm{t}-1}+\varepsilon_{\mathrm{i}}
\end{aligned}
$$

Null Hypothesis: DELEK has a unit root

Exogenous: Constant

Lag Length: 0 (Automatic - based on $\mathrm{SIC}$, maxlag=2)

\begin{tabular}{lccc}
\hline \hline & t-Statistic & \multirow{2}{*}{ Prob. $^{*}$} \\
\hline \hline Augmented Dickey-Fuller test statistic & -3.499506 & \multirow{2}{*}{0.0262} \\
\hline Test critical values: & $1 \%$ level & -4.057910 & \\
& $5 \%$ level & -3.119910 & \\
& $10 \%$ level & -2.701103 & \\
\hline \hline
\end{tabular}

*MacKinnon (1996) one-sided p-values.

Warning: Probabilities and critical values calculated for 20 observations and may not be accurate for a sample size of 13

The direction of the causality relationship was measured by Granger causality analysis.

It was found that the growth in GDP can be explained by Total Electricity Consumption.

Pairwise Granger Causality Tests

Date: 08/10/19 Time: 13:30

Sample: 20002017

Lags: 1

\begin{tabular}{lccl}
\hline \hline Null Hypothesis: & Obs & F-Statistic & Prob. \\
\hline \hline DBUY does not Granger Cause DELEK & 17 & 1.23718 & 0.2920 \\
DELEK does not Granger Cause DBUY & & 8.25415 & 0.0166 \\
\hline \hline
\end{tabular}

\section{Relationship Between electricity use and economic growth}

Electrical energy, which is a secondary energy source obtained from different energy sources, is one of the most important elements of the economic growth and development of the countries both in terms of being 
one of the inputs of the industry and being used widely in daily life.

This has enabled electrical energy to maintain its importance for many years in terms of efficiency and ease of use. With the development of countries, demand has increased,

There is a close relationship among of economic growth and development of countries and the use of energy resources. Therefore, there is a close relationship between the use of electrical energy and the increase in production capacity and the economic growth and development of countries.

The World Economic Outlook published by the IMF states that although the energy demand of OECD countries, representing more than half of the total production of the world economy, has increased by almost $2 \%$ in the last ten years, the world demand for electricity has been 1 point above this figure.

According to the most recent Annual Energy Outlook published by the EIA, electricity production in OECD countries has doubled in the last 30 years. However, most of this increase is met by fossil fuels and nuclear energy. The share of electricity generated from renewable energy sources remains around $20 \%$. It is also noteworthy that the use of nuclear energy has more than doubled in the last twenty years. (Uçak, 2010: 56) Economic growth of OECD countries is below the average of the world and developing countries with an average rate of $2 \%$. Moreover, the increase in electricity production of these countries is below the growth figures by $1.5 \%$.

In terms of electricity production and consumption in our country, the table is in a course resembling the profile of OECD countries.

Table 1. Annual Development of Turkey's Installed Capacity (MW)

\begin{tabular}{|l|l|l|l|l|l|}
\hline Year & Thermal & Hydro & $\begin{array}{l}\text { Geothermal+Wind } \\
\text { Solar }\end{array}$ & Total & $\mathbf{( \% )}$ \\
\hline $\mathbf{2 0 0 0}$ & 16052,5 & 11175,2 & 36,4 & 27264,1 & 4,4 \\
\hline $\mathbf{2 0 0 1}$ & 16623,1 & 11672,9 & 36,4 & 28332,4 & 3,9 \\
\hline $\mathbf{2 0 0 2}$ & 19568,5 & 12240,9 & 36,4 & 31845,8 & 12,4 \\
\hline $\mathbf{2 0 0 3}$ & 22974,4 & 12578,7 & 33,9 & 35587,0 & 11,7 \\
\hline $\mathbf{2 0 0 4}$ & 24144,7 & 12645,4 & 33,9 & 36824,0 & 3,5 \\
\hline $\mathbf{2 0 0 5}$ & 25902,3 & 12906,1 & 35,1 & 38843,5 & 5,5 \\
\hline $\mathbf{2 0 0 6}$ & 27420,2 & 13062,7 & 81,9 & 40564,8 & 4,4 \\
\hline $\mathbf{2 0 0 7}$ & 27271,6 & 13394,9 & 169,2 & 40835,7 & 0,7 \\
\hline $\mathbf{2 0 0 8}$ & 27595,0 & 13828,7 & 393,5 & 41817,2 & 2,4 \\
\hline $\mathbf{2 0 0 9}$ & 29339,1 & 14553,3 & 868,8 & 44761,2 & 7,0 \\
\hline $\mathbf{2 0 1 0}$ & 32278,5 & 15831,2 & 1414,4 & 49524,1 & 10,6 \\
\hline $\mathbf{2 0 1 1}$ & 33931,1 & 17137,1 & 1842,9 & 52911,1 & 6,8 \\
\hline $\mathbf{2 0 1 2}$ & 35027,2 & 19609,4 & 2422,8 & 57059,4 & 7,8 \\
\hline $\mathbf{2 0 1 3}$ & 38648,0 & 22289,0 & 3070,5 & 64007,5 & 12,2 \\
\hline $\mathbf{2 0 1 4}$ & 41801,8 & 23643,2 & 4074,8 & 69519,8 & 8,6 \\
\hline $\mathbf{2 0 1 5}$ & 41903,0 & 25867,8 & 5375,9 & 73146,7 & 5,2 \\
\hline $\mathbf{2 0 1 6}$ & 44411,6 & 26681,1 & 7404,7 & 78497,4 & 7,3 \\
\hline $\mathbf{2 0 1 7}$ & 46926,3 & 27273,1 & 11000,6 & 85200,0 & 8,5 \\
\hline & & Source TEİAS, Electricty Statistic & & \\
\hline
\end{tabular}

Source: TEİAS, Electricty Statistic.

As in the world, electric energy is an important production input for many sectors in our country. It should be kept in mind that the development of industries, which are one of the driving elements of both economic growth and development, depends on meeting the energy needs. 
Table 2.The Distrubution of Imported Electrical Energy by Countries (GWH)

\begin{tabular}{|l|l|l|l|l|l|l|l|}
\hline & Bulgaria & Greece & Russia & Azerbaijan & Georgia & Iran & Total \\
\hline $\mathbf{2 0 0 0}$ & 3296,9 & & & & 204,7 & 289,7 & 3791,3 \\
\hline $\mathbf{2 0 0 1}$ & 3775,5 & & & & 523,0 & 280,9 & 4579,4 \\
\hline $\mathbf{2 0 0 2}$ & 3445,4 & & & & 92,7 & 50,1 & 3588,2 \\
\hline $\mathbf{2 0 0 3}$ & 1134,5 & & & & & 23,5 & 1158,0 \\
\hline $\mathbf{2 0 0 4}$ & & & & & & 463,5 & 463,5 \\
\hline $\mathbf{2 0 0 5}$ & & & & & 101,1 & 534,8 & 635,9 \\
\hline $\mathbf{2 0 0 6}$ & & & & 40,5 & 532,7 & 573,2 \\
\hline $\mathbf{2 0 0 7}$ & & & & 15,3 & 215,6 & 633,4 & 864,3 \\
\hline $\mathbf{2 0 0 8}$ & & 29,9 & & 94,0 & 215,5 & 450,0 & 789,4 \\
\hline $\mathbf{2 0 0 9}$ & & & & 125,3 & 182,1 & 504,5 & 812,0 \\
\hline $\mathbf{2 0 1 0}$ & & & & 156,0 & 303,2 & 684,6 & $1.143,8$ \\
\hline $\mathbf{2 0 1 1}$ & 2094,1 & 838,7 & & 329,9 & 218,6 & 1074,5 & $4.555,8$ \\
\hline $\mathbf{2 0 1 2}$ & 3966,8 & 3,7 & & 277,4 & 79,0 & 1499,8 & $5.826,7$ \\
\hline $\mathbf{2 0 1 3}$ & 4571,2 & 173,2 & & 276,7 & 3,3 & 2405,0 & $7.429,4$ \\
\hline $\mathbf{2 0 1 4}$ & 5300,7 & 4,0 & & 102,7 & 293,9 & 2252,0 & $7.953,3$ \\
\hline $\mathbf{2 0 1 5}$ & 4842,0 & 8,4 & & 0 & 417,5 & 1867,7 & 7135,5 \\
\hline $\mathbf{2 0 1 6}$ & 4587 & 68,3 & & 0 & 1039,3 & 635,8 & 6330,3 \\
\hline $\mathbf{2 0 1 7}$ & 2073 & & & 0 & 493,9 & 160,8 & 2728,3 \\
\hline
\end{tabular}

Source: TEİAŞ, Electricty Statistic.

As it can be seen from the tables, especially after 2011, parallel to the increase in the demand for electricity, the method of outsourcing was mainly used. Especially after 2009, with Turkey's economic growth rate in GDP growth and the change of position in the ranking of the world economy shows parallels between this situations. This shows the close relationship between the use of electricity and economic growth.

To date, our country has obtained a significant portion of its electricity from natural gas. Considering that natural gas is a non-renewable energy source, this situation must be changed.

Turkey, an important part of the energy needs from imports. This also applies to the supply of electrical energy. In addition, in terms of the use of electrical energy in the industry, despite the low value added within the industry, it is seen that the production branches such as iron-steel, aluminum, cement and paper have a significant share in the amount of energy consumed. This is an issue that cannot be ignored in terms of efficiency in energy use. (Uçak, 2010). In this respect, increasing energy efficiency is of great importance. Although developed countries produce more with lower energy input, this is not the case because of the low intensity of advanced technology use in developing countries.

However, in the long-term energy policy objectives in Turkey, rather than the energy efficiency of energy supply continuity, reliability, and is known to focus on providing low cost.

In particular, studies revealing a strong relationship between electrical energy consumption and economic growth and economic development highlight the close relationship between energy efficiency and economic growth. 
International Journal of Scientific and Technological Research ISSN 2422-8702 (Online), DOI: 10.7176/JSTR/5-8-09

Table 3. The Distrubution of Exported Electrical Energy by Countries (GWH)

\begin{tabular}{|l|l|l|l|l|l|l|l|l|}
\hline Year & Bulgaria & Georgia & Azerbaycan & İran & Iraq & Syria & Greece & Total \\
\hline $\mathbf{2 0 0 0}$ & & & 437,3 & & & & & 437,3 \\
\hline $\mathbf{2 0 0 1}$ & & & 432,8 & & & & & 432,8 \\
\hline $\mathbf{2 0 0 2}$ & & & 435,1 & & & & & 435,1 \\
\hline $\mathbf{2 0 0 3}$ & & & 401,5 & & 186,1 & & & 587,6 \\
\hline $\mathbf{2 0 0 4}$ & & & 378,7 & & 765,6 & & & 1144,3 \\
\hline $\mathbf{2 0 0 5}$ & & 9,3 & 384,1 & & $1.404,7$ & & & $1.798,1$ \\
\hline $\mathbf{2 0 0 6}$ & & 106,7 & 325,7 & & $1.668,8$ & 134,5 & & $2.235,7$ \\
\hline $\mathbf{2 0 0 7}$ & & 117,5 & 14,9 & & 1237,2 & 962,4 & 90,2 & $2.422,2$ \\
\hline $\mathbf{2 0 0 8}$ & & 54,3 & 0,03 & & 911,6 & 97,3 & 58,9 & $1.122,2$ \\
\hline $\mathbf{2 0 0 9}$ & & 0,002 & 0,078 & & 1215,0 & 330,7 & & $1.545,8$ \\
\hline $\mathbf{2 0 1 0}$ & & & 0,345 & 0,038 & 1288,1 & 629,1 & & $1.917,6$ \\
\hline $\mathbf{2 0 1 1}$ & 621,8 & 0,003 & 19,400 & & 42,5 & 1170,6 & 1790,30 & $3.644,6$ \\
\hline $\mathbf{2 0 1 2}$ & 1,7 & & 12,900 & & & 1234,1 & 1704,90 & $2.953,6$ \\
\hline $\mathbf{2 0 1 3}$ & 0,2 & 0,100 & 0,200 & & 421,6 & 0,0 & 804,70 & $1.226,7$ \\
\hline $\mathbf{2 0 1 4}$ & 0,2 & 0,9 & 0,1 & & 785,4 & 0,0 & 1909,4 & $2.696,0$ \\
\hline $\mathbf{2 0 1 5}$ & 1,9 & 2,2 & & & 371,8 & & 2818,6 & 3194,5 \\
\hline $\mathbf{2 0 1 6}$ & 3,1 & & & & 4,3 & 1444,3 & 1451,7 \\
\hline $\mathbf{2 0 1 7}$ & 98 & 0,8 & & & & & 3204,9 & 3303,7 \\
\hline
\end{tabular}

Source: TEİAŞ, Electricty Statistic.

Table 4. Primary Energy Sources from which electricity is obtained

\begin{tabular}{|l|c|c|c|c|c|c|}
\hline & $\begin{array}{c}\text { Jan } \\
\mathbf{2 0 1 4} \\
\mathbf{( \% )}\end{array}$ & $\begin{array}{c}\text { Jan } \\
\mathbf{2 0 1 5}\end{array}$ & $\begin{array}{c}\text { Dec } \\
\mathbf{2 0 1 4} \\
\mathbf{( \% )}\end{array}$ & $\begin{array}{c}\text { March } \\
\mathbf{2 0 1 8} \\
\mathbf{( \% )}\end{array}$ & $\begin{array}{c}\text { March } \\
\mathbf{2 0 1 9} \\
\mathbf{( \% )}\end{array}$ & $\begin{array}{c}\text { Feb } \\
\mathbf{2 0 1 9} \\
\mathbf{( \% )}\end{array}$ \\
\hline Natural Gas & 51 & 48 & 48 & 26 & 18 & 16 \\
\hline Hydro (Dam) & 14 & 6 & 6 & 14 & 21 & 22 \\
\hline Hydro (Stream) & 3 & 6 & 6 & 11 & 11 & 9 \\
\hline Coal (Import) & 12 & 17 & 17 & 18 & 19 & 23 \\
\hline Lignite & 15 & 15 & 15 & 15 & 16 & 15 \\
\hline Coal & 1 & 1 & 1 & 1 & 1 & 1 \\
\hline Fuel oil & 1 & 2 & 2 & 0 & 1 & 1 \\
\hline Wind & 2 & 4 & 4 & 8 & 9 & 8 \\
\hline Geothermal & 1 & 1 & 1 & 2 & 3 & 3 \\
\hline
\end{tabular}

Source: EİGM, Monthly Energy Statistics Report, March 2019. 
In the last fifty years, a unidirectional causality in Turkey in terms of electricity consumption and economic growth have been identified. (Altınay and Karagöl, 2005) In contrast, studies conducted for the same period for some countries called Asian tigers have found a two-way causality relationship.(Yang, 2000) In the period the last quarter of the 20th century, especially in studies for Latin American countries, unidirectional causality which determines the look works like Turkey. (Yoo, 2006)

InTurkey, according to March 2019 data, the total amount of electricity consumption was 23.791.621 MWh and increased by 5.1\% compared to the previous month. Per capita electricity consumption in March 2019 decreased by 3.8\% compared to March 2018 and was realized as $29 \mathrm{kWh}$. (EIGM, 2019)

Table 5. Gross domestic product (Turkey) (2000-2017)

\begin{tabular}{|c|c|c|c|c|c|c|}
\hline \multirow[b]{2}{*}{$\prod_{0}^{\infty}$} & \multicolumn{2}{|c|}{ Constant prices } & \multicolumn{2}{|c|}{ Current prices } & \multirow{2}{*}{$\begin{array}{l}\text { Deflator } \\
\text { (Index) }\end{array}$} & \multirow[b]{2}{*}{$\begin{array}{c}\text { Economic } \\
\text { Growth }(\%)\end{array}$} \\
\hline & $\begin{array}{l}\text { (National } \\
\text { currency) } \\
\text { (Billions) }\end{array}$ & $\begin{array}{c}\text { (Percent } \\
\text { change) }\end{array}$ & $\begin{array}{l}\text { (National } \\
\text { currency) } \\
\text { (Billions) }\end{array}$ & $\begin{array}{c}\text { (U.S. } \\
\text { Dollars) } \\
\text { (Billions) }\end{array}$ & & \\
\hline 2000 & 731.577 & 6.640 & 170.667 & 273.085 & 23.329 & 6,8 \\
\hline 2001 & 687.958 & -5.962 & 245.429 & 200.305 & 35.675 & $-5,7$ \\
\hline 2002 & 732.195 & 6.430 & 359.359 & 238.342 & 49.080 & 6,2 \\
\hline 2003 & 773.259 & 5.608 & 468.015 & 311.944 & 60.525 & 5,3 \\
\hline 2004 & 847.834 & 9.644 & 577.024 & 404.853 & 68.059 & 9,4 \\
\hline 2005 & 924.223 & 9.010 & 673.703 & 501.163 & 72.894 & 8,4 \\
\hline 2006 & 989.933 & 7.110 & 789.228 & 550.796 & 79.725 & 6,9 \\
\hline 2007 & $1,039.731$ & 5.030 & 880.461 & 675.010 & 84.682 & 4,6 \\
\hline 2008 & $1,048.519$ & 0.845 & 994.783 & 764.643 & 94.875 & 0,7 \\
\hline 2009 & 999.192 & -4.704 & 999.192 & 644.470 & 100.000 & $-4,7$ \\
\hline 2010 & $1,083.997$ & 8.487 & $1,160.014$ & 772.290 & 107.013 & 9,2 \\
\hline 2011 & $1,204.467$ & 11.113 & $1,394.477$ & 832.497 & 115.775 & 8,8 \\
\hline 2012 & $1,262.160$ & 4.790 & $1,569.672$ & 873.696 & 124.364 & 2,2 \\
\hline 2013 & $1,369.334$ & 8.491 & $1,809.713$ & 950.328 & 132.160 & 3,3 \\
\hline 2014 & $1,440.083$ & 5.167 & $2,044.466$ & 934.075 & 141.969 & 5,2 \\
\hline 2015 & $1,527.725$ & 6.086 & $2,338.648$ & 859.449 & 153.080 & 6,1 \\
\hline 2016 & $1,576.365$ & 3.184 & $2,608.526$ & 863.390 & 165.477 & 3,2 \\
\hline 2017 & $1,693.666$ & 7.441 & $3,106.537$ & 851.521 & 183.421 & 7,4 \\
\hline
\end{tabular}

Source: IMF, 2019

\section{Conclusion}

It is known that developing countries are trying to increase their production in order to meet the increasing consumption. However, it is also a known fact that environmental problems make it difficult to supply energy. Achieving economic growth and responding to increasing consumption, trying to improve the quality of life for many years is only possible with sustainable development.

The Kyoto Protocol and other international legal arrangements emphasize the importance of production techniques that protect the ecological balance in the selection of energy types. During both production and use, electrical energy is a type of energy that takes into account environmental sensitivity. It is also of great importance in terms of leaving an intact environment for future generations.

From today to tomorrow, it is imperative to turn to energy types derived from renewable sources and / or secondary energy sources, rather than energy sources derived from fossil sources. The use of electrical energy, which ranks first among these energy types, also maintains its importance as an indicator of development.

Nevertheless, the fact that energy production from renewable resources requires a high budget in terms of 
initial establishment cost and that this applies to the acquisition of electrical energy forces countries to turn to fossil fuels, ignoring the environmental facts. However, this choice is a strategic mistake in terms of achieving a long-term economic development target and sustainability.

It is of utmost importance that our country and all countries of the world turn to renewable energy sources or secondary energy sources from renewable energy sources in order to achieve economic growth without compromising sustainable development and environmental awareness and without distancing from the realities of the world economic conjuncture we live in.

The widespread worldview of the 21 st century links economic growth and development with consumption. In order to make consumption, it is inevitable to increase the share of renewable energy sources or the energy sources obtained by using these sources. In this respect, economic growth and the expansion of the use of electric energy, especially in the industry, is a necessary issue for the growth of countries.

The causality tests used in this study can give three different results. These are the absence of a relationship between the variables, the presence of one-way relationship and the presence of two-way relationship. In the Granger causality test between 2000-2017 data, total electricity consumption and growth were found to be the cause of growth. In other words, the increase in electricity consumption contributes to the increase in growth, but no conclusions have been obtained to confirm the opposite.

The expected relationship between the two variables is that electricity consumption increases and growth increases. The results were in line with the expectations.

In particular, it can be concluded that as the electrical energy used in the production process increases, this is due to the increase in production and increases in production support economic growth.

In line with the objective of improving Turkey's economic growth, the increase in total electricity consumption used towards achieving this goal is a positive reference

\section{References}

Acaroğlu, Mustafa (2007). Alternatif Enerji Kaynakları, Nobel Akademik Yayıncılık, Ankara.

Akarca, A.T., LONG, T.V. (1980). "On the Relationship between Energy and GNP, Journal of Energy and Development, Cilt: 5, ss.326-331.

Altınay, Galip ve Erdal Karagöl (2005). "Electricity Consumption and Economic Growth: Evidence from Turkey”, Energy Economics Dergisi, Cilt: 27, Say1: 6, ss. 827-846.

Aydal, Doğan (2008). Petrolsüz Dünya, Truva Yayınları, İstanbul.

Bakırtaş, Tahsin, Sohbet Karbuz ve Melike Bildirici (2000). "An Econometric Analysis Of Electricty Demand In Turkey", METU Studies in Development Dergisi, Cilt: 27, Sayı:1, ss. 23 34.

Başol, Koray, Mustafa Durman ve Hüseyin Önder (2007). Doğal Kaynakların ve Çevrenin Ekonomik Analizi, Alfa Yayınevi, İstanbul.

Begg, David, Stanley Fischer ve Rudiger Dornbusch (1994). Economics, Literatür Yayınevi, 4. Basım, İstanbul.

Bozlagan, Recep (2005). "Sürdürülebilir Gelişme Düşüncesinin Tarihsel Arka Planı”, Sosyal Siyaset Konferansları Dergisi, Say1: 50, ss. 1012-1026.

Brown, Lester R. (2003). Eko-Ekonomi, Çev. A. Yeşim Erkan, Tema Yayınları, İstanbul.

Çukurçayır, M. Akif ve Hayriye Sağır (2008). "Enerji Sorunu, Çevre ve Alternatif Enerji Kaynakları”, Selçuk Üniversitesi Sosyal Bilimler Enstitüsü Dergisi, Say1: 20, ss.258-275.

Demirbaş, Ayhan. (2006). “Turkey’s Renewable Energy Policy”, Energy Sources Dergisi, Cilt: 27, Say1: 1, ss. 657-665.

Doğan, Seyhun (2005). “Türkiye’nin Küresel İklim Değişikliğinde Rolü ve Önleyici Küresel Çabaya Katılım Girişimleri”, C.Ü. İktisadi ve İdari Bilimler Dergisi, Cilt:6, Sayı 2, ss. 57-72.

87 | P a g e

www.iiste.org 
Eray, Aynur (2001). Enerjide Tutumluluk ve Verimlilik, Temiz Enerji Vakfi, Ankara.

Erdoğdu, Erkan (2009). "On The Wind Energy in Turkey", Renewable and Sustainable Energy Reviews Dergisi, Cilt: 13, Say1: 6-7, ss.1361-1371.

Ferguson, Rose, William Wilkinson ve Robert Hill (2000). "Electricty Use and Economic Development", Energy Policy, Cilt: 28, Say1: 13, ss. 5-52.

Ghosh, Sajal (2002). "Electicity Consumption and Economic Growth in India", Energy Policy, Cilt: 30, Say1: 2, ss.125-129.

Goswami, Yogi (2007). Survey of Energy Resources, World Energy Counsil Press, London.

Güler, Önder (2009). "Wind Energy Status in Electrical Energy Production of Turkey”, Renewable and Sustainable Energy Reviews, Cilt: 13, Sayı: 2, ss. 473-478.

Halıcıoğlu, Ferda (2007). "Residential Electricity Demand Dynamics in Turkey", Energy Economics, Cilt: 29, Say1: 2, ss.199-210.

IEA (2015). World Energy Outlook, IEA Press, Paris.

ITO (1999). Türkiye' de Elektrik Enerjisi Sektöründe Özelleştirme Politikaları ve Çalışmaları, Midas Yayınları, İstanbul.

Kaygusuz, Kamil (2003). “Energy Policy and Climate Change İn Turkey”, Energy Conversion and Management, Cilt: 44, Say1: 10, ss. 1671-1688.

Kar, Muhsin (2001). "Finansal Kalkınma ve Ekonomik Büyüme: Nedensellik İlişkisi”, Dokuz Eylül Üniversitesi İşletme Fakültesi Dergisi, Cilt: 2, Sayı: 2, ss.150-169.

Karagöl, Erdal, Erman Erbaykal ve Ertuğrul H. Murat (2007). “Türkiye'de Ekonomik Büyüme ile Elektrik Tüketimi İlişkisi: Sınır Testi Yaklaşımı”, Doğuş Üniversitesi Dergisi, Cilt:8, Sayı:1, ss. $72-80$.

Kılıçanka, Fatma ve Durmuş Kaya (2007). "Energy Production, Consumption, Policies and Recent Developments in Turkey", Renewable \& Sustainable Energy Reviews, Cilt: 11, Say1: 6, ss. 1312-1320.

Kraft, John ve Arthur Kraft (1978). "On The Relationship between Energy and GNP”, Journal of Energy and Development, Say1: 3, ss.401-403.

Kum, Hakan (2009). "Yenilenebilir Enerji Kaynakları: Dünya Piyasalarındaki Son Gelişmeler ve Politikalar”, Erciyes Üniversitesi İ̈BF Dergisi, Sayı: 33, ss. 207-223.

Kuznets, Simon (1995). "Economic Growth and İncome Inequality", American Economic Review, Cilt: 42, Sayı: 1, ss. 1-28.

Murry, D.A ve NAN, G.D. (1996). "A Definition Of The Gross Domestic Product-Electirification Interrelationship", The Journal of Energy and Development, Cilt: 19, Sayı: 2, ss. 275-283.

Nişancı, Murat (2005). "Türkiye'de Elektrik Enerjisi Talebi ile Ekonomik Büyüme Arasındaki İlişki”, SÜ İIBF Sosyal ve Ekonomik Araştırmalar Dergisi, Sayı: 9, ss. 107-118.

Öztürk, Lütfü (2007). Sürdürülebilir Kalkınma, İmaj Yayınevi, Ankara.

Sahin, M. (2008). “Kyoto Protokolü ve Türkiye”, Çevre ve İnsan, Sayı: 73-2. 
Sarı, Ramazan, Uğur Soytaş ve ÖZDEMİR, Ö. (2001) "Energy Consumption and GDP Relations in Turkey: A Cointegration and Vector Error Analysis", Economies and Business in Transition: Facilitating Competitiveness and Change in the Global Environment Proceedings ss.838-844.

Soytaş, Uğur ve Ramazan Sarı (2007). "The Relationship Between Energy and Production: Evidence from Turkish Manifacturing Industry" Energy Economics, Cilt: 29, Sayl: 6, ss. 11511165.

Stern, David I.(1993). "Energy and Economic Growth in The USA: A Multivariate Approach", Energy Economics, Cilt: 15, Say1: 2, ss. 137-150.

TEİAS (2015). Türkiye Elektrik Üretim İletim İstatistikleri.

Terzi, Harun (1998). "Türkiye'de Elektrik Tüketimi ve Ekonomik Büyüme İlişkisi: Sektörel bir Karşlaştırma”, İşletme ve Finans Dergisi, Cilt:13, Sayı: 144, ss.62-71.

Uçak, Sefer (2010). Sürdürülebilir Kalkınma Bağlamında Alternatif Enerji ve Enerji ÜretimiBüyüme İlişkisi: Panel Veri Analizi, Doktora Tezi, Kocaeli Üniversitesi, Sosyal Bilimler Enstitüsü, Kocaeli.

UNDP (2014). Human Development Report, UNDP Press, New York.

Yamak, Rahmi ve Bayram Güngör (1998). "Konut Elektrik Talep Denkleminin Tahmini: Türkiye Örneği, 1950-1991”, Ekonomik Yaklaşım, Cilt: 9, Say1: 31, ss.71-78.

Yang, Hao-Yen (2000). "A Note on the Casual Relationship between Energy and GDP in Taiwan", Energy Economics, Cilt: 22; Say1: 3, ss. 309-317.

Yoo, Seung-Hoon. ve Kim Yeonnbae (2006). "Electricity Generation and Economic Growth in Indonesia", Energy, Cilt: 34, Say1: 14, ss. 2890-2899. 